\title{
PEMIKIRAN POSTMODERNISME DAN PANDANGANNYA TERHADAP ILMU PENGETAHUAN
}

\section{Johan Setiawan}

Program Pascasarjana Universitas Negeri Yogyakarta

Email: johansetiawan767@,gmail.com

\section{Ajat Sudrajat}

Program Pascasarjana Universitas Negeri Yogyakarta

Email: ajat@uny.ac.id

\section{Abstrak}

Lahirnya postmodernisme tidak dapat dilepaskan dari adanya paham modernisme. Pandangan modernisme menganggap bahwa kebenaran ilmu pengetahuan bersifat mutlak dan objektif, artinya tidak adanya nilai dari manusia. Di sinilah lahir suatu paham baru yaitu postmodernisme yang salah satu tokohnya bernama Jean Francouis Lyotard, postmodernisme merupakan kelanjutan dan koreksi dari modernisme untuk memberikan suatu pemikiran baru dan solusi dalam pandangannya terhadap ilmu pengetahuan. Penelitian ini merupakan penelitian kepustakaan. Metode yang digunakan dalam penelitian ini adalah metode hermeneutika filosofis, dengan unsur-unsur: interpretasi, deskripsi, dan komparasi. Hasil penelitian menunjukkan bahwa bagi postmodernisme, ilmu pengetahuan tidaklah bersifat objektif tetapi subjektif dan interpretasi dari manusia itu sendiri, sehingga kebenarannya adalah relatif. Postmodernisme tidak lepas dengan adanya kelemahannya dan apakah relevan terhadap kehidupan masa kini, maka terlepas dari itu postmodernisme menambah pembendaraan pengetahuan yang dapat diterima keberadaannya.

Kata kunci: postmodernisme, modernisme, ilmu pengetahuan

\section{Abstract}

The birth of postmodernism can not be separated from the notion of modernism. The view of modernism assumes that the truth of science is absolute and objective, meaning that there is no human value. Here is the birth of a new idea of postmodernism which is one of figures are Jean Francouis Lyotard, postmodernism is a continuation and correction of modernism to provide a new 
thought and solution in his view of science. This study is a literature. The method used in this research is a philosophical hermeneutic method, with the following elements: interpretation, description, and comparison. The research show that postmodernism, science is not objective but subjective and the interpretation of man himself, so the truth is relative. Postmodernism can not be separated by its weakness and whether it is relevant to today's life, so postmodernism adds to the acquisition of knowledge which can be accepted by its existence.

Keywords: postmodernism, modernism, science

\section{PENDAHULUAN}

Perkembangan pemikiran dari waktu ke waktu terus mengalami perubahan dalam berbagai hal, tentunya hal itu tidak lepas dari keinginan manusia yang selalu menginginkan sebuah perubahan karena bertambahnya persoalan dan juga kebutuhan. Kalau kita kembali pada masa terdahulu tentunya tidak mengherankan lagi terhadap sebuah perkembangan dalam berbagai ranah kehidupan, terlebih lagi dalam soal keilmuan. Kehidupan terus berputar dan berkembang seiring dengan semakin bertambahnya manusia sehingga melahirkan pemikiran dan terus berupaya untuk mengembangkan kehidupannya dalam berbagai hal.

Demikian juga dalam hal ilmu pengetahuan tentunya selalu mengalami perkembangan dari tahun ketahun ataupun dari abadkeabad. Karena sifat dari manusia yang memang selalu tidak merasa puas terlebih dalam hal keilmuan. Akibat dari hasil pemikiran yang telah ada, mereka akan berfikir untuk dapat mengembangkan bahkan melakukan sebuah pengujian ulang terhadap hasil penemuan yang telah lalu. Misalkan dalam bidang filsafat kita mengenal yang namanya Anaximander (610-546 SM) yang mengatakan bahwa substansi asal itu bukan air. Berbeda dengan filosof sebelumnya Thales (624-545 SM) mengatakan bahwa zat pertama dan utama terbentuknya sesuatu itu adalaha air (Maksum, 2012: 44-45). Dan seterusnya mengalami perubahan dan perkembangan tentunya dalam rangka untuk menuju pada suatu yang lebih sempurna seiring dengan perkembangan dan kemajuan pemikiran manusia. 
Sama halnya dengan postmodernisme yang muncul diakibatkan karena kegagalan Modernisme dalam mengangkat martabat manusia. Bagi postmodernisme, paham modernisme selama ini telah gagal dalam menepati janjinya untuk membawa kehidupan manusia menjadi lebih baik dan tidak adanya kekerasan. Perkembangan ilmu pengetahuan dan teknologi masa modernisme membawa kehancuran bagi manusia, peperangan terjadi dimana-mana yang hal ini mengakibatkan manusia hidup dalam menderita. Pandangan modernisme menganggap bahwa kebenaran ilmu pengetahuan harus mutlak serta objektif, tidak adanya nilai dari manusia. Di sinilah muncul suatu paham postmodernisme yang merupakan kelanjutan, keterputusan, dan koreksi dari modernisme untuk memberikan suatu pemikiran baru dan solusi dalam menjalani kehidupan yang semakin kompleks ini. Bagi postmodernisme ilmu pengetahuan tidaklah objektif tetapi subjektif dan interpretasi dari manusia itu sendiri, sehingga kebenarannya adalah relatif.

Dalam penulisan ini penulis akan membahas secara fokus dan rinci terhadap paham postmodernisme yang merupakan pengembangan pemikiran tentang ilmu pengetahuan, yang merupakan pergeseran, perkembangan bahkan kelanjutan dari modernisme itu sendiri. Tentunya hal ini akibat dari pergolakan pemikiran dari para pemikir yang peduli terhadap ilmu pengetahuan, sehingga memunculkan suatu pemikiran baru.

Berdasarkan latar belakang diatas, maka rumusan masalah dalam penelitian ini adalah bagaimanakah pemikiran postmodernisme dan pandangannya terhadap ilmu pengetahuan? Sedangkan tujuan penelitian ini untuk mengetahui pemikiran postmodernisme dan pandangannya terhadap ilmu pengetahuan.

\section{PENGERTIAN POSTMODERNISME}

Jean-Francois Lyotard adalah orang yang memperkenalkan postmodernisme dalam bidang filsafat dan ilmu pengetahuan di tahun 1970-an dalam bukunya yang berjudul "The Postmodern Condition: A Report on Knowledge". Dia mengartikan postmodernisme sebagai segala 
kritik atas pengetahuan universal, atas tradisi metafisik, fondasionalisme maupun atas modernisme (Maksum, 2014: 305-306).

Menurut beberapa para ahli yang lainnya, seperti Louis Leahy, postmodernisme adalah suatu pergerakan ide yang menggantikan ideide zaman modern (Leahy, 1985: 271). Menurut Emanuel, postmodernisme adalah keseluruhan usaha yang bermaksud merevisi kembali paradigma modern (Emanuel, 2006: 93). Sedangkan menurut Ghazali dan Effendi, postmodernisme mengoreksi modernisme yang tidak terkendali yang telah muncul sebelumnya (Ghazali \& Effendi, 2009: 161).

Maka dapat disimpulkan bahwa postmodernisme merupakan suatu ide baru yang menolak atau pun yang termasuk dari pengembangan suatu ide yang telah ada tentang teori pemikiran masa sebelumnya yaitu paham modernisme yang mencoba untuk memberikan kritikan-kritikan terhadap modernisme yang dianggap telah gagal dan bertanggung jawab terhadap kehancuran martabat manusia; ia merupakan pergeseran ilmu pengetahuan dari ide-ide modern menuju pada suatu ide yang baru yang dibawa oleh postmodernisme itu sendiri.

\section{LAHIRNYA POSTMODERNISME}

Munculnya postmodernisme tidak dapat dilepaskan dari modernisme itu sendiri. Kata modernisme mengandung makna serba maju, gemerlap, dan progresif. Modernisme selalu menjanjikan pada kita untuk membawa pada perubahan ke dunia yang lebih mapan di mana semua kebutuhan akan dapat terpenuhi. Rasionalitas akan membantu kita menghadapi mitos-mitos dan keyakinan-keyakinan tradisional yang tak berdasar, yang membuat manusia tak berdaya dalam menghadapi dunia ini (Maksum, 2014: 309).

Namun demikian, modernisme memiliki sisi gelap yang menyebabkan kehidupan manusia kehilangan diorientasi. Apa yang dikatakan oleh Max Horkheimer, Ardono, dan Herbert Marcuse bahwa pencerahan tersebut melahirkan sebuah penindasan dan dominasi disamping juga melahirkan kemajuan.

Modernisme, menurut Anthony Giddens, menimbulkan berkembangbiaknya petaka bagi umat manusia. Pertama, penggunaan 
kekerasan dalam menyelesaikan sengketa. Kedua, penindasan oleh yang kuat atas yang lemah. Ketiga, ketimpangan sosial yang kian parah. Keempat, kerusakan hidup yang kian menghawatirkan (Maksum, 2014: 311).

Tumbangnya modernisme dan munculnya postmodernisme dapat kita ketahui dari pemikiran filsafatnya Soren Kierkegaard (1813-1855), sebagaimana dikutip oleh Ali Maksum, yang menentang rekonstruksirekonstruksi rasional dan masuk akal yang menentukan keabsahan kebenaran ilmu. Sesuatu itu dikatakan benar ketika sesuai dengan konsensus atau aturan yang berlaku di dunia modern, yaitu rasional dan objektif. Namun tidak dengan Kierkegaard, dia berpendapat bahwa kebenaran itu bersifat subjektif (Ghazali \& Effendi, 2009: 314). Truth is subjectivity, artinya bahwa pendapat tentang kebenaran subjektif itu menekankan pentingnya pengalaman yang dialami oleh seorang individu yang dianggapnya relatif.

Gejala Postmodernisme yang merambah ke berbagai bidang kehidupan tersebut yang didalamnya termasuk ilmu pengetahuan merupakan suatu reaksi terhadap gerakan modernisme yang dinilainya mengalami kegagalan. Modernisme yang berkembang dengan ditandai oleh adanya rasionalisme, materialisme, dan kapitalisme yang didukung dengan perkembangan teknologi serta sains menimbulkan disorientasi moral keagamaan dengan runtuhnya martabat manusia (Kalean, 2002: 298).

Atas latar belakang itulah, para tokoh dan pemikir postmodernisme menghadirkan sebuah gagasan baru yang disebut dengan postmodernisme dalam rangka melakukan dekonstruksi paradigma terhadap berbagai bidang keilmuan, sebagai sebuah upaya untuk mengoreksi atau membuat dan bahkan menemukan paradigma yang baru. Postmodernisme seperti yang dikatakan oleh Derrida dan Lyotard, merupakan anti tesis dari modernisme. Hampir semua istilah yang diajukan oleh postmodernisme adalah antonimasi modernisme. Kelahiran postmodernisme membuat istilah baru dan mengakibatkan perbedaan dengan paham modernisme. Berikut ini beberapa istilah yang digunakan oleh aliran modernisme dan postmodernisme atau pembeda antara keduanya (Maksum, 2014: 348): 


\begin{tabular}{|l|l|}
\hline \multicolumn{1}{|c|}{ MODERNISME } & \multicolumn{1}{|c|}{ POSTMODERNISME } \\
\hline Sentralisasi & Desentralisasi \\
Pertarungan Kelas & Pertarungan Etnis \\
Konstruksi & Dekonstruksi \\
Kultur & Sub-Kultur \\
Hermeneutis & Nihilisme \\
Budaya Tinggi & Budaya Rendah \\
Hierarki & Anarki \\
Industri & Pasca-Industri \\
Teori & Paradigma \\
Kekuatan Negara & Kekuatan Bersama \\
Agama & Sekte-sekte \\
Legitimasi & Delegitimasi \\
Konsensus & Dekonsensus \\
Budaya Tradisional & Liberalisme \\
Kontinuitas & Diskontinuitas \\
\hline
\end{tabular}

\section{TOKOH-TOKOH POSTMODERNISME}

Ada beberapa tokoh yang bisa disebut mewakili era Postmodernisme. Pertama, Jean-Francois Lyotard, merupakan salah satu filsuf postmodernisme yang paling terkenal sekaligus paling penting di antara filsuf-filsuf postmodernisme yang lainnya. Dua karya yang menjadikannya terkenal baik di Perancis maupun diluar negeri yaitu The Postmodernisme Condition dan The Differend. Karyanya itu juga baik sesuatu ataupun seseorang yang ditolak bersuara terhadap sistem ideologis yang dominan yang menentukan sesuatu yang dapat diterima dan tidak dapat diterima (Zaprulkhan, 2006: 320).

Pemikiran Lyotard tentang ilmu pengetahuan dari pandangan modernisme yang sebagai narasi besar seperti kebebasan, kemajuan, dan sebagainya kini menurutnya mengalami permasalahan yang sama seperti abad pertengahan yang memunculkan istilah religi, nasional kebangsaan, dan kepercayaan terhadap keunggulan negara eropa untuk saat ini tidak dapat dipercaya atau kurang tepat kebenarannya. Maka, postmodernisme menganggap sesuatu ilmu tidak harus langsung diterima kebenarannya harus diselidiki dan dibuktikan 
terlebih dahulu. Bagi Lyotard, ilmu pengetahuan postmodernisme bukanlah semata-mata menjadi alat penguasa, ilmu pengetahuan postmodern memperluas kepekaan kita terhadap pandangan yang berbeda dan memperkuat kemampuan kita untuk bertoleransi atas pendirian yang tak mau dibandingkan (Maksum, 2014: 319-321).

Kedua, Michel Foucault, adalah seorang tokoh postmodernisme yang menolak keuniversalan pengetahuan. Ada beberapa asumsi pemikiran pencerahan yang ditolak oleh Foucault yaitu:

1) Pengetahuan itu tidak ersifat metafisis, transendental, atau universal, tetapi khas untuk setiap waktu dan tempat

2) Tidak ada pengetahuan yang mampu menangkap katakter objektif dunia, tetapi pengetahuan itu selalu mengambil perspektif.

3) Pengetahuan tidak dilihat sebagai pemahaman yang netral dan murni, tetapi selalu terikat dengan rezim-rezim penguasa (Maksum, 2014: 322).

Namun demikian, menurut Foucault, tidak ada perpisahan yang jelas, pasti, dan final antara pemikiran pencerahan dan pasca-modern, atau antara modern dan pasca-modern. Paradigma modern, kesadaran, dan objektivitas adalah dua unsur membentuk rasionalotonom, sedangkan bagi Foucault pengetahuan bersifat subjektif.

Ketiga, Jacques Derrida. Membahas filsuf yang satu ini tidak akan lepas dari buah pikirannya tentang dekonstruksi. Istilah ini merupakan salah satu konsep kunci postmodernisme. Apa itu dekonstruksi? secara etimologis, dekonstruksi adalah berarti mengurai, melepaskan, dan membuka (Maksum, 2014: 331).

Derrida menciptakan sebuah pemikiran dekonstruksi, yang merupakan salah satu kunci pemikiran postmodernisme, yang mencoba memberikan sumbangan mengenai teori-teori pengetahuan yang dinilai sangat kaku dan kebenarannya tidak bisa dibantah, yang dalam hal ini pemikiran modernisme. Derrida mencoba untuk meneliti kebenaran terhadap suatu teori pengetahuan yang baginya bisa dibantah kebenarannya yang dalam arti bisa membuat teori baru asalkan hal tersebut dapat terbukti kebenarannya dan dipertanggungjawabkan. 
Keempat, Jean Baudrillard; pemikirannya memusatkan perhatian kepada kultur, yang dilihatnya mengalami revolusi besar-besaran dan merupakan bencana besar. Revolusi kultural itu menyebabkan massa menjadi semakin pasif ketimbang semakin berontak seperti yang diperkirakan pemikir marxis. Dengan demikian, massa dilihat sebagai lubang hitam yang menyerap semua makna, informasi, komunikasi, pesan dan sebagainya, menjadi tidak bermakna. Massa menempuh jalan mereka sendiri, tak mengindahkan upaya yang bertujuan memanipulasi mereka. Kekacauan, apatis, dan kelebaman ini merupakan istilah yang tepat untuk melukiskan kejenuhan massa terhadap tanda media, simulasi, dan hiperealitas (Maksum, 2014: 338).

Bagi Jean Baudrillard, karya-karyanya mempunyai sumbangan terhadap pemikiran teori sosial untuk postmodernisme yang baginya bahwa objek konsumsi merupakan tatanan produksi. Sehingga baginya masyarakat hidup dalam simulasi yang dicirikan dengan ketidakbermaknaan. Karena manusia kehilangan identitasnya dan jati dirinya yang banyak terjadi pada masa kontenporer. Tokoh inilah yang terkenal dengan menyebut dunia postmodernisme sebagai kehidupan yang Hiperealitas.

Kelima, Fedrick Jameson. Ia merupakan salah satu kritikus literatur berhaluan marxis paling terkemuka. George Ritzer dalam Postmodern Social Theori, menempatkan Jameson dengan Daniel Bell, kaum feminis dan teoritis multikultur. Jameson menggunakan pola berfikir Marxis untuk menjelaskan epos historis yang baru (postmodernisme), yang baginya bukan modification dari kapitalisme, melainkan ekspansi darinya. Dengan demikian, menjadi jelas bahwa periode historis yang ada sekarang bukanlah keterputusan, melainkan kelanjutannya (Maksum, 2014: 339).

Menurut Jameson, postmodernisme memiliki dua ciri utama, yaitu pastiche dan schizofrenia. Jameson mulai dengan menjelaskan bahwa modernisme besar didasarkan pada gaya yang personal atau pribadi. Subjek individual borjois tidak hanya merupakan subjek masa lalu, tapi juga mitos subjek yang tidak pernah benar-benar ada, hanya mistifikasi, kata Jameson, yang tersisa adalah pastiche. Pastiche dari pastiche, tiruan gaya yang telah mati. Kita telah kehilangan kemampuan memposisikan ini secara historis. Postmodernisme 
memiliki konsep waktu yang khas. Jameson, menjelaskan apa yang ia maksudkan dengan menggunakan teori schizofrena lacan. Schizofrenik adalah pengalaman penanda material yang terpisah, terisolir, dan gagal membentuk rangkaian yang koheren (Hidayat, 2008: 227).

\section{CIRI-CIRI PEMIKIRAN POSTMODERNISME}

Amin Abdullah dalam bukunya berjudul Falsafah Kalam di Era Postmodernisme menyatakan bahwa ciri-ciri pemikiran postmodernisme adalah dekonstruktif. Hampir semua bangunan atau konstruksi dasar keilmuan yang telah mapan dalam era modern, baik dalam bidang sosiologi, psikologi, antropologi, sejarah, bahkan juga ilmu-ilmu kealaman yang selama ini baku ternyata dipertanyakan ulang oleh postmodernisme. Hal ini terjadi karena teori tersebut dianggap menutup munculnya teori-teori lain yang barangkali jauh lebih dapat membantu memahami realitas dan pemecahan masalah. Jadi klaim adanya teori-teori yang baku, standar, yang tidak dapat diganggu gugat, itulah yang ditentang oleh pemikir postmodernisme.

Standar yang dilihatnya kaku dan terlalu skematis sehingga tidak cocok untuk melihat realitas yang jauh lebih rumit. Maka menurutnya harus diubah, diperbaiki, dan disempurnakan oleh para pemikir postmodernisme. Dalam istilah Amin Abdullah dikenal dengan deconstructionism yakni upaya mempertanyakan ulang teori-teori yang sudah mapan yang telah dibangun oleh pola pikir modernisme, untuk kemudian dicari dan disusun teori yang lebih tepat dalam memahami kenyataan masyarakat saat ini, meliputi keberagaman, dan juga realitas alam (Abdullah, 2004: 96).

Ciri postmodernisme yang lain adalah berwatak relativisme, artinya pemikiran postmodernisme dalam hal realitas budaya (nilainilai, kepercayaan, dan lainnya) tergambar dalam teori-teori yang dikembangkan oleh disiplin ilmu antropologi. Dalam pandangan antropologi, tidak ada budaya yang sama dan sebangun antara satu dengan yang lain. Seperti budaya Amerika jelas berbeda dengan Indonesia. Maka nilai-nilai budaya jelas sangat beraneka ragam sesuai dengan latar belakang sejarah, geografis, dan sebagainya. 
Berdasarkan penjelasan di atas, nampak bahwa nilai-nilai budaya bersifat relatif, dan hal ini sesuai dengan alur pemikiran postmodernisme yaitu bahwa wilayah, budaya, bahasa, agama sangat ditentukan oleh tata nilai dan adat istiadat masing-masing. Dari sinilah Nampak jelas bahwa para pemikir postmodernisme menganggap bahwa segala sesuatu itu relatif dan tidak boleh absolut, karena harus mempertimbangkan situasi dan kondisi yang ada.

Dapat disimpulkan bahwa ilmu pengetahuan bagi postmodernisme bersifat relatif, tidak ada ilmu pengetahuan yang kebenarannya absolut. Dan melihat suatu peristiwa tertentu juga ketika ingin menilainya harus dilihat dari segala sisi, tidak hanya terfokus pada satu sisi tertentu.

Pluralisme merupakan ciri pemikiran postmodernisme selanjutnya. Hasil teknologi modern dalam bidang transportasi dan komunikasi menjadikan era pluralisme budaya dan agama telah semakin dihayati dan dipahami oleh banyak orang dimanapun mereka berada. Adanya pluralisme budaya, agama, keluarga, ras, ekonomi, sosial, suku pendidikan, ilmu pengetahuan, politik merupakan sebuah realitas. Artinya bahwa mentoleransi adanya keragaman pemikiran, peradaban, agama dan budaya (Abdullah, 2004: 104). Sehingga menciptakan suatu adanya heterogen, bermacam-macam bukan homogen. Keanekaragaman ini harus ditoleransi antara satu dengan yang lainnya bukan saling menjatuhkan apalagi sampai terjadinya suatu konflik tertentu.

\section{TEORI-TEORI SOSIAL POSTMODERNISME}

Beberapa teori sosial postmodernisme antara lain, pertama, Teori Sosial Postmodern Moderat. Teori ini yang menyatakan bahwa ada keterputusan antara modernisme dengan postmodernsme. Namun ada yang mengatakan bahwa kendati postmodernisme memiliki perbedaan penting dengan modernisme, namun ada semacam persambungan antara keduanya (Ritzer \& Goodman, 2012: 671).

Meskipun ada perbedaan penting dalam jarak waktu antara modernisme ke postmodernisme, namun ada kesinambungan antara keduanya. Proposisi ini yang digarap Jameson. Prinsipnya, kapitalisme yang dalam perkembangannya kini berada pada fase lanjutannya 
masih menjadi gambaran dominan, tetapi telah menimbulkan logika kultural baru, yang disebut sebagai postmodernisme.

Masyarakat postmodern, menurut Jameson, terdiri atas empat unsur yaitu: Pertama, masyarakat postmodern ditandai dengan kedangkalan dan kekurangan kedalaman. Kedua, masyarakat postmodern ditandai oleh kepura-puraan atau kelesuan emosi. Ketiga, masyarakat postmodern ditandai oleh hilangnya kesejarahan. Dan, keempat, masyarakat postmodern ditandai sejenis teknologi baru yang berkaitan erat dengan masyarakat postmodern itu sendiri. Misalnya, teknologi seperti telivisi atau teknologi elektronik.

Kedua, Teori Sosial Postmodern Ekstrem, teori ini menyatakan bahwa masyarakat moden telah digantikan oleh masyarakat postmodern. Menurutnya objek konsumsi merupakan "sesuatu yang diorganisir oleh tatanan produksi" atau "perluasan kekuatan produktif yang diorganisir" (Maksum, 2014: 337). Teori ini dudukung salah satunya oleh Jean Baudrillard. Jean Baudrillard adalah sosiolog teori Postmodern paling radikal dan menimbulkan banyak amarah dalam genre ini yang berfikiran mengenai keadaan sosial masyakarat saat ini yang dipengaruhi oleh berbagai produksi yang memperlihatkan keadaan sesungguhnya masyarakat itu (Ritzer \& Goodman, 2009: 676).

Bagi Jean Baudrillard, masyarakat saat ini tidak lagi didominasi oleh produksi, tetapi didominasi kepada media dan siberanertika serta industri dan sebagainya. Di saat masyarakat telah didominasi oleh kode produksi dan dikontrol olehnya maka hal ini bertujuan dari eksploitasi dan laba menuju kearah tanda dan sistem (Ritzer \& Goodman, 2009: 677). Menurut Baudrillard, menggambarkan dunia postmodern ditandai oleh simulasi, sulit untuk melihat hal-hal yang riil (Ritzer \& Goodman, 2009: 678). Baudrillard juga menggambarkan dunia ini sebagai Hipperealitas. Contohnya media mulai tidak lagi menjadi cermin realitas melainkan menjadi lebih riil dari realitas (Ritzer \& Goodman, 2009: 677). Hipperealitas itu adalah efek, atau keadaan dan pengalaman kebendaan atau ruang yang dihasilkan dari proses tersebut (Piliang, 2003: 150).

Ketiga, Posisi Teoritis; teori ini bepandangan bahwa perbedaan pandangan antara modernisme dan postmodernisme bukan lagi 
dijadikan sebuah perdebatan, akan tetapai bagaimana keduanya bisa saling bergandengan dan saling melengkapi. Kelompok ini berpendapat ketimbang mempersoalkan modernisme dan postmodernisme sebagai era kesejarahan atau waktu, lebih baik melihat modernisme dan postmodernisme sebagai kekuatan yang selalu menjalin hubungan seiring sejalan satu sama lain. Dengah menempatkan postmodernisme secara berkesinambungan berupaya untuk selalu menunjukkan keterbatasan-keterbatasan modernisme. Posisi ketiga ini dapat dianggap sebagai alternatif di luar sikap yang mendudukkan modernisme dan postmodernisme dalam kategori waktu. Representasi terpenting dari aliran ini tak lain adalah JeanFrancois Lyotard (Norris, 2003: 7).

\section{KELEBIHAN DAN KELEMAHAN POSTMODERNISME}

Kelebihan postmodernisme antara lain bahwa perspektif postmodernisme dapat membuat kita peka terhadap kemungkinan bahwa wacana besar positif, prinsip-prinsip etika positif, dapat diputar dan dipakai untuk menindas manusia. Martabat manusia harus dijunjung tinggi, seperti kebebasan adalah nilai tinggi, tetapi bisa saja terjadi bahwa nama kebebasan sekelompok orang mau ditiadakan. Postmodernisme ikut membuat kita sadar, sebuah kesadaran bahwa semua cerita besar perlu dicurigai, perlu diwaspadai agar tidak menjelma rezim totalitarianisme yang hanya mau mendengarkan suara diri sendiri dan mengharuskan suara-suara yang berbeda dari luar (Zaprulkhan, 2006: 323-324). Menurut Franz Dahler, postmodernisme memiliki segi positif, yaitu keterbukaan untuk kebhinekaan masyarakat, untuk toleransi, perlawanan terhadap monopoli, dominan agama, aliran dan ideologi tertentu, hingga menguntungkan demokrasi (Jalaluddin, 2013: 67).

Zaprulkhan menyatakan bahwa setidaknya ada kelemahan yang ada pada postmodernisme, yang penulis rangkum menjadi tiga poin utama, yaitu, pertama, postmodernisme yang sangat semangat mempromosikan narasi-narasi kecil, ternyata buta terhadap kenyataan bahwa banyak juga narasi kecil yang mengandung banyak kebusukan. Katakanlah kaum komunitarian yang membela tradisi-tradisi komunitas dikemukakan bahwa banyak tradisi komunitas 
bertentangan tidak hanya dengan suatu ide abstrak martabat manusia postmodernisme akan menolak argumen itu, melainkan terhadap institusi-institusi moral mendalam manusia. Kedua, postmodernisme tidak membedakan antara ideologi, di satu pihak dan prinsip-prinsip universal etika terbuka, di pihak lain. Dengan istilah-istilah kabur seperti cerita besar mereka menutup perbedaan yang prinsipil itu. Yang mempermudah adalah pendekatan ideologis dan bukan nilainilai dan prinsip-prinsip dasar moralitas yang terbuka. Dalam arti ideologi tertutup, memang bertentangan dengan martabat manusia sebagai makluk yang bertindak berdasarkan kesadaran akan baik dan buruk, yang sanggup untuk bertanggung jawab, karena ideologi selalu menuntut ketaatan mutlak. Dan yang ketiga Postmodernisme menuntut untuk menyingkirkan cerita-cerita besar demi cerita kecil atau lokal. Dengan kata lain tuntutan postmodernisme kontradiktif, memaklumkan kepada umat manusia bahwa maklumat-maklumat kepada umat manusia (cerita besar) harus ditolak sama artinya dengan memaklumatkan bahwa maklumat itu sendiri tidak perlu dihiraukan (Zaprulkhan, 2006: 322-323).

\section{KRITIK TERHADAP POSTMODERNISME}

Habermas dalam bukunya, The Philosophical of Modernity, mengkritik postmodernisme menyatakan bahwa asal-usul konsep postmodernity itu sendiri harus diteliti. Habermas menyatakan ada kelemahan mendasar pemikiran kaum postmodernis tentang modernitas yang dianggap ahistoris. Para pemikir postmodernisme seakan-akan menghilangkan dimensi dan cakrawala historis yang memunculkan postmodern itu.

Ali Maksum menyatakan bahwa kritik atas postmodernisme antara lain: a) Pemikir postmodernisme kurang tegas apakah mereka menciptakan teori atau mengarang sastra; b) Habermas merasa argumen para postmodernis sarat dengan sentimen normatif, namun sentimen mereka itu disembunyikan dari pembaca, Habermas mengemukakan sentimen normatifnya (kebebasan, keterbukaan, komunikasi) yang dijadikan sumber kritiknya terhadap masyarakat serta menjadi basis bagi praktis politiknya; c) Habermas mengkritik 
postmodernisme sebagai perspektif yang gagal membedakan fenomena dan praktik yang terjadi pada masyarakat modern. contohnya tentang pandangan dunia yang didominasi oleh kekuasaan dan pengawasan tidak memberikan peluang yang cukup baik untuk melakukan analisis yang bermakna atas sumber nyata penindasan dalam kehidupan modern; d) Pemikir postmodernisme dituduh mengabaikan praktik kehidupan dunia. Kekeliruan ini merupakan kerugian ganda bagi pemikir postmodernisme. Di satu sisi, mereka sumber penting perkembangan standar normatif. Sedangkan disisi lain, mereka menjadikan kehidupan dunia sebagai tujuan akhir karya ilmu sosial (Maksum, 2014: 340, 345-346).

\section{PANDANGAN POSTMODERNISME TEHADAP ILMU PENGETAHUAN}

Modernisme memandang ilmu-ilmu positif empiris atau ilmu pengetahuan mau tidak mau menjadi standar kebenaran tertinggi. Artinya pandangan modernisme yang objektif dan positivis. Mengakibatkan nilai moral dan religious kehilangan wibawa. Maka timbul disorientasi moral-religius menuju suatu kekerasan, keterasingan, dan disorientasi hidup (Norris, 2003: 312).

Penganut postmodernisme mengakui adanya suatu pendekatan dalam ilmu pengetahuan yaitu secara pendekatan metodologis antara lain interpretasi anti obyektifitas dan dekonstruksi. Postmodernisme dipahami sebagai interpretasi tak terbatas (Soetriono \& Hanafie, 2007: 31). Dengan demikian dalam pandangan postmodernisme bahwa ilmu pengetahuan bersifat subjektif. Implikasinya adalah bahwa tidak ada apa yang dinamakan ilmu bebas nilai. Sedangkan modernisme menganggap ilmu pengetahuan yang objektif maka bebas dari nilai (Jalaluddin, 2013: 67).

Sehingga penganut postmodernisme tidak mengakui akan adanya rasionalitas universal, yang ada hanyalah relativitas dari eksistensi plural. Maka, dengan demikian, perlu dirubah dari berfikir totalizing menjadi pluralistic and open democracy dalam semua sendi kehidupan. Pandangan postmodernisme lebih menekankan pluralitas, perbedaan, heterogenitas, budaya lokal/etnis, dan pengalaman hidup sehari-hari. 
Jadi, postmodernisme memandang bahwa ilmu pengetahuan yang ditawarkan oleh modernisme akan membawa pada kehancuran. Modernisme tidak membawa kita pada kehidupan yang lebih layak dan bisa mengangkat harkat martabat manusia seperti apa yang telah dijanjikannya, namun malah sebaliknya. Postmodernisme berpandangan, harus dilakukan perombakan terhadap apa yang ditawarkan oleh modernisme dan juga harus dikaji ulang terlebih dahulu.

\section{RELEVANSI DISCOURSE POSTMODERNISME DALAM ILMU PENGETAHUAN}

Bagi pemikiran postmodernisme, mereka tidak memandang ilmu pengetahuan modern sebagai universalisme. Karena postmodernisme menolak penjelasan yang berifat universal, harmonis, atau bahkan konsisten. Kaum postmodernisme menggantikan hal tersebut kepada yang partikular dan lokal, lalu menyingkirkan hal yang bersifat universal. Watak yang menonjol dari era postmodernisme ini mengangkat konsep pluralisme, penekanan kepada konsepsi empiris dalam arti penekanan pada nilai individualitas dari manusia sebagai sang otonom.

Ciri-ciri dari postmodernisme melingkupi hal-hal secara konseptual discourse ide yang meliputi: 1) ide yang menghendaki penghargaan besar terhadap alam ini sebagai kritik atas gerakan modernisme yang mengeksploitasi alam, 2) ide yang menekankan pentingnya bahasa dalam kehidupan manusia dengan segala konsep dan analisanya yang kompleks, ini sebagai antitesa atas kondisi modernisme atas kuasa tafsir oleh mesin birokrasi ilmu pengetahuan, 3) ide besar untuk mengurangi kekaguman terhadap ilmu pengetahuan, kapitalisme, dan teknologi yang muncul dari perkembangan modernisme. Dengan alasan bahwa semua itu telah melahirkan konstruksi manusia sebagai obyek yang mati dalam realitas kehidupannya. Sehingga menjauhkan manusia dari humanismenya itu sendiri; 4) ide pentingnya inklusivitas dalam menerima tantangan agama lain atas agama dominant sehingga terbuka munculnya ruang dialogis. Ini muncul sebagai akibat 
menjamurnya dan tumbuhkembangnya realitas modernis yang menempatkan ideologi sebagai alat pembenar masing-masing; 5) sikap yang cenderung permisive dan menerima terhadap ideologi dan juga agama lain dengan berbagai penafsiran; 6) secara kasuistik munculnya ide pergeseran dominasi kulit putih di dunia barat; 7) merupakan ideide cemerlang yang menjadi daya dorong kebangkitan golongan tertindas, seperti golongan ras, gender, kelas minoritas secara sosial yang tersisihkan; 8) ide tentang tumbuhnya kesadaran akan pentingnya interdependensi secara radikal dari semua pihak dengan cara yang dapat dan memungkinkan terpikirkan oleh manusia secara menyeluruh (Muhlisin, 2000: 6-7).

Ciri yang paling dominan dari pemikiran postmodernisme diatas mengacu kepada ide dasar yang ingin mengurangi kekaguman serta memberi kritik terhadap suatu ilmu pengetahuan. Hal ini dapat diartikan ia menunjukkan adanya pergeseran yang cukup signifikan atas era modernitas ke era postmodernisme. Cukup jelas bagi gerakan postmodernisme bahwa memahami fenomena modern yang bernama pengetahuan, khususnya menyangkut pengetahuan sosial. Ia mempertanyakan tentang "apa itu pengetahuan yang benar" secara genealogis dan arkeologis. Dapat diartikan dengan melacak bagaimana pengetahuan itu mengembangkan diri selama ini. Misalnya konseptual tentang "kegilaan", "seksualitas", manusia", "gender" dan lain sebagainya yang biasa dianggap "natural" itu sebenarnya adalah situs-situs produksi dari ilmu pengetahuan (Muhlisin, 2000: 7).

\section{RELEVANSI POSTMODERNISME BAGI KEHIDUPAN MASA KINI}

Jika diamati dengan saksama, banyak hal menarik dan bisa diterima dari apa yang ditawarkan oleh pasca-modernisme. Lepas dari sah atau tidaknya keberadaan pasca-postmodernisme, kenyataannya dia ada dan keberadaannya harus diakui. Soal membawa manfaat atau tidaknya, kita tidak bisa menilai secara langsung dengan satu sisi saja, karena selalu ada dua sisi yaitu apakah baik atau buruk. Kita bisa memeriksa dan menjelaskan apa yang telah diterangkan diatas. Tentunya, pormodernisme telah menambah perbendaraan kita mengenai ilmu pengetahuan. Maka dari itu, pada bagian ini, akan 
mencoba untuk menganalisis secara kritis apa saja prinsip-prinsip yang ditawarkan oleh aliran postmodernisme tersebut (Maksum, 2014: 352).

Pandangan postmodernisme yang kelanjutan dari modernisme muncul karena menentang pendapat dari modernisme yang mereka anggap memiliki kelemahan, bukan berarti bahwa postmodernisme terlepas dari adanya kelemahan. Tampak penjelasan diatas dapat peneliti sebutkan bahwa aliran postmodernisme ini muak dan lelah akan metanarasi dari era modern, mereka beralasan bahwa metanarasi itu bisa mengarahkan kita pada marginalisasi cerita-cerita kecil baik dari kehidupan kita yang nyata di kehidupan sehari-hari maupun secara tradisi, kepercayaan masyarakat dan komunitas setempat (Maksum, 2014: 352). Paham Postmodernisme ini ingin menghilangkan pendasaran umum dan ingin melihat cerita-cerita yang kecil. Ceritacerita kecil seperti Desentralisasi, Pertarungan Etnis, Dekonstruksi, SubKultur, Nihilisme, Budaya Rendah, Anarki, Pasca-Industri, Paradigma, Kekuatan Bersama, Sekte-sekte, Delegitimasi, Dekonsensus, Liberalisme, dan Diskontinuitas yang merupakan kebalikan atau antithesis dari paham modernisme.

Hal itu karena kurang masuk akal sebab untuk menilai atau menangkap suatu cerita (kerangka) dasar diperlukan suatu dasar pijakan. Karena hal ini tanpa adanya kerangka atau dasar pijakan tersebut kita tidak bisa bicara apa-apa. Selain itu kita tidak hanya berpegang pada cerita-cerita lokal atau keyakinan setempat, sangat sulitlah untuk mengambil keputusan dan yang terjadi adalah siapa yang kuat, itulah yang akan menjadi pemenang (Maksum, 2014: 352).

Dengan kata lain hal itu sudah terbukti bahwa jika kita menengok proses peradilan hukum di Indonesia yang sering kali orang kecil menjadi korban hanya karena buta hukum dan hukum itu ditafsirkan sesuai dengan keinginan pihak tertentu yang tentunya mempunyai suatu power. Pada titik ini juga dikhawatirkan akan terjadi kontradiksi. Manusia yang tidak memiliki kekuatan apapun atau istilah kata sebagai rakyat jelata dihadapan hukum akan mengalami kekalahan, dibandingkan dengan seseorang yang paham hukum dan memiliki kekuatan hukum. 
Karena apabila pasca-modernisme menyangkal prinsip-prinsip (metanarasi), maka dengan sendirinya akan muncul prinsip-prinsip baru (narasi-narasi kecil) karena menyangkal prinsip berarti juga berprinsip dan itulah kontradiksinya, seperti pernah dialami oleh kaum skeptif itu sendiri mereka yakin bahwa pernyataan itu harusnya benar, padahal dengan pernyataan tersebut berarti pernyataan kaum spektif bahwa semua kenyakinan kita perlu diragukan juga tidak benar dan karena itu, jangan berkeyakinan seperti itu (Maksum, 2014: 353).

Jika hal itu terjadi mengenai tidak menyakini suatu pernyataan, maka kembali kepada kaum spektif yang setiap pernyataannya tidak harus ditanggapi dengan kebenaran. Perkataan kaum spektif bisa dibantahkan bahkan mereka setiap pendapatnya tidak dipercaya. Lalu apa yang harus dilakukan, maka yang dilakukan perlu adanya dekonstruksi mengenai kebenaran. Tetapi tidak semua dihilangkan bahkan dihapuskan. Tetapi jika ada kesalahan dan kurang tepat maka bisa diperbaiki. Dekonstruksi tidak semua narasi-narasi besar dilakukan, tetapi narasi yang dimana pantas untuk di dekonstruksikan.

Cerita-cerita besar itu sangat diperlukan, dan cerita besar itu cenderung menjadi sebuah ideologi, itulah sebenarnya yang harus diwaspadai. Karena banyak cerita-cerita besar atau paham-paham besar dapat membawa penderitaan bagi umat manusia, misalnya sebagai contoh kita sebut saja paham komunisme. Paham komunisme ini bisa membawa penderitaan kepada umat manusia yang mengikuti ketentuannya. Walaupun tujuannya segala sesuatu milik bersama, tidak memiliki secara individu, tetapi paham ini dalam penerapannya menggunakan pemaksaan dan kekerasan kepada para pengikutnya agar mengikuti dan mentaati paham ini. Dan juga tidak jarang bahwa ideologi-ideologi religius justru membawa kesengsaraan dan membelenggu umat manusia. Maka, di sinilah perlu adanya dekonstruksi cerita besar sehingga diharapkan tidak menyeleweng dari misinya yang sejak lama dibawanya (Maksum, 2014: 353).

Pertanyaannya mengapa ideologi perlu didekonstruksikan, sebab ia menyangkal hal cerita kecil, ideologi itu bersifat mutlak. Benar berarti sesuai dengan ideologi, yang sesuai disikat abis, dengan kebenaran ideologi tertentu, tidak segan-segan seseorang akan 
memusnakannya. Padahal sesuatu hal bagi postmodernisme tidak mutlak, mereka percaya bahwa kebenaran bersifat relatif. Disesuaikan dengan segala aspek pengliatan, bukan hanya terfokus pada sisi tertentu saja.

Jadi, menurut peneliti maka dekonstruksi sangat dibutuhkan dan perlu, tetapi untuk itu haruslah jeli dan butuh pemikiran yang cerdas untuk mengawasi dan mengkritisi cerita atau narasi mana yang perlu direvisi atau didekonstruksi. Pascamodernisme menjadi kurang cerdas jika kita menganggap semua cerita besar itu perlu didekonstruksikan. Sayangnya pascamodernisme tidak mampu melakukan hal seperti itu. Dekonstruksi yang sebenarnya, kata Frans Magniz-Suseno, adalah menganalisis dengan teliti. Di sini cerita atau narasi yang besar itu benar, cerita tentang harkat martabat kemanusiaan cerita bahwa situasi apapun tak pernah boleh untuk di pakai semata-mata sebagai sebuah sarana, cerita hak-hak asasi manusia, justru malah akan bertahan.

Dengan melihat sisi negatif dari paham postmodernisme itu, maka apakah dengan demikian postmodernisme harus di hapus atau dibuang. Tentu sisi positifnya tetap ada, ia telah mengingatkan kepada kita bahwasanya dalam diri kita harus waspada terhadap teori atau cerita atau narasi besar jangan sampai mereka berkembang menjadi sebuah ideologi. Jangan sampai ideologi tersebut berlindung dibalik teori-teori besar tersebut. Tetapi kenyataannya bahwa dibalik itu semua ia menghalalkan segala cara untuk mencapai tujuan-tujuan pribadi. Paham postmodernisme tetap dapat dikembangkan dan dapat dipercaya asal ia tidak memutlakkan prinsip dia sendiri dengan menghilangkan prinsip orang lain. Karena segala sesuatu itu perlu diteliti atau bahkan dikoreksi dan dipertanyakan apakah ia benar berjuang demi menegakkan martabat dan kebahagiaan manusia yang lebih benar (Maksum, 2014: 354).

Selain pada itu, yang perlu kita kembangkan dan kita tegakan dari paham postmodernisme adalah sikap saling menghargai manusia sebagai individu-individu dengan segala keunikan dan keberagamanya yang meliputi kelemahan dan kelebihan adalah suatu nilai lebih dan unik, hal itu membedakan kepada yang lainnya. Bukan kita untuk mempermasalahkan keberagaman itu tetapi bagaimana hal 
itu menjadi suatu kegembiraan dan kekhasan terhadap apa yang dimiliki. Dengan menyadari hal tersebut lah, posrmodernisme memberikan suatu hak untuk menyuarakan pendapatnya dan ia terus menjalankan sifat emansipatorisnya. Jadi dengan demikian kita harus memegang kedua-duanya, yang universal dan yang lokal, menghargai cerita atau teori atau narasi besar yang memang memperjuangkan martabat manusia dan juga harus menghargai cerita-cerita kecil seperti pluralisme dalam keanekaragaman itu sebagai anda penghargaan manusia-manusia individu asal memperkembangkan individu tersebut, dengan demikian kehidupan kita menjadi tercerahkan (Maksum, 2014: 354).

\section{SIMPULAN}

Jean-Fracois Lyotard adalah orang yang memperkenalkan postmodernisme dalam bidang filsafat dan ilmu pengetahuan di tahun 1970-an dalam bukunya yang berjudul "The Postmodern Condition: A Report on Knowledge". Dia mengartikan postmodernisme sebagai segala kritik atas pengetahuan universal, atas tradisi metafisik, fondasionalisme maupun atas modernisme. Menurut Louis, postmodernisme adalah suatu pergerakan ide yang menggantikan ideide zaman modern

Gejala postmodernisme yang merambah ke berbagai bidang kehidupan tersebut yang didalamnya termasuk ilmu pengetahuan merupakan suatu reaksi terhadap gerakan modernisme yang dinilainya mengalami kegagalan. Modernisme yang berkembang dengan ditandai oleh rasionalisme, materialisme, dan kapitalisme yang didukung oleh sains dan teknologi mengakibatkan timbulnya disorientasi moral keagamaan (religius) terutama runtuhnya martabat manusia.

Tokoh-tokoh Postmodernisme antara lain Jean-Francois Lyotard, Michael Foucault, Jacques Derrida, Jean Baudrillard, dan Fedrick Jameson. Ciri-ciri pemikiran postmodernisme antara lain Dekonstruktifisme, Relativisme, dan Pluralisme. Teori sosial dalam Postmodernime terdapat beberapa aliran yaitu : Postmodern Moderat, Postmodern Ekstrem, dan Posisi Teoritis. Pandangan postmodernisme tehadap ilmu pengetahuan bahwa mereka tidak mengakui akan 
adanya rasionalitas universal, objektif dalam pengetahuan. Yang ada hanyalah relativitas dari eksistensi plural atau subjektivitas. Maka dengan demikian perlu dirubah dari berfikir totalizing menjadi pluralistic and open democracy dalam semua sendi kehidupan.

Kelebihannya postmodernisme dapat membuat kita peka terhadap kemungkinan bahwa wacana besar positif, prinsip-prinsip etika positif, dapat diputar dan dipakai untuk menindas manusia. Menurut Franz Dahler, postmodernisme memiliki segi positif, yaitu keterbukaan untuk kebhinekaan masyarakat, untuk toleransi, perlawanan terhadap monopoli, dominan agama, aliran dan ideologi tertentu, hingga menguntungkan demokrasi. Sedangkan kelemahan postmodernisme, pertama, postmodernisme yang sangat semangat mempromosikan narasi-narasi kecil, ternyata buta terhadap kenyataan bahwa banyak juga narasi kecil yang mengandung banyak kebusukan. Kedua, postmodernisme tidak membedakan antara ideologi, di satu pihak dan prinsip-prinsip universal etika terbuka, di pihak lain. Ketiga, postmodernisme menuntut untuk menyingkirkan cerita-cerita besar demi cerita kecil atau lokal.

Kritik terhadap postmodernisme antara lain pemikir postmodernisme kurang tegas terhadap membedakan apakah mereka menciptakan teori atau mengarang sastra. Habermas merasa argumen para postmodernis sarat dengan sentimen normatif. Ciri discourse postmodernisme dalam ilmu pengetahuan memahami fenomena modern yang bernama pengetahuan. Ia mempertanyakan tentang "apa itu pengetahuan yang benar" secara genealogis dan arkeologis, dalam arti, dengan melacak bagaimana pengetahuan itu mengembangkan diri selama ini. Misalnya konseptual tentang "kegilaan", "seksualitas", manusia", "gender" dan lain sebagainya yang biasa dianggap "natural" itu sebenarnya adalah situs-situs produksi dari ilmu pengetahuan.

Relevansi postmodernisme saat ini karena mereka bersikap saling menghargai manusia sebagai individu-individu dengan segala keunikan yang ada pada dirinya dan keberagamanya yang meliputi kelemahan dan kelebihan adalah suatu nilai lebih dan unik, hal itu merupakan pembeda dengan yang lainnya. Bukan kita untuk 
mempermasalahkan keberagaman itu tetapi bagaimana hal itu menjadi suatu kegembiraan dan kekhasan terhadap apa yang dimiliki.

\section{DAFTAR PUSTAKA}

Abdullah, Amin, 2004, Falsafah Kalam di Era Postmodernisme, Pustaka Pelajar, Yogjakarta.

Aginta, Medhy Hidayat, 2008, Panduan Pengantar Untuk Memahami Postrukturalisme dan Posmodernisme, Jalasutra Post, Yogyakarta.

Ghazali, Abd. Moqsith \& Djohan Effendi,2009, Merayakan kebebasan Beragama: Bunga Rampai Menyambut 70 Tahun Djohan Effendi, Penerbit Buku Kompas, Jakarta.

Jalaluddin, 2013, Filsafat Ilmu Pengetahuan, Rajawali Pers, Jakarta.

Kalean, 2002, Filsafat Bahasa, Paradigma, Yogyakarta.

Leahy, Louis, 1985, Manusia Sebuah Misteri Sintesa Filosofis Makhluk Paradoks, Gramedia, Jakarta.

Maksum, Ali, 2012, Pengantar Filsatfat, Ar-ruzz mmedia, Jakarta. 2014, Pengantar Filsafat: Dari Masa Klasik hingga Posmodernisme, Ar-Ruzz Media, Yogyakarta.

Muhlisin, Postmodernisme dan Kritik Ideologi Ilmu Pengetahuan Modern. Jurnal Okarra II. Vol 1 No 1 Tahun 2000.

Norris, Chistopher, 2003, Membonkar teori dekonstruksi Jacques Derrida Arruss, Yogyakarta.

Piliang, Yasraf Amir, 2003, Hipersemiotika, Tafsir Cultural Studies atas Matinya Makna, Jalasutra, Bandung.

Ritzer, George R. dan Douglas J. Goodman, 2009, Teori Sosiologi: Dari Teori Sosiologi Klasik sampai Perkembangan Mutakhir Teori Sosial Postmodern, Kreasi Wacana, Yogyakarta.

2012, Teori Sosiolog, Kreasi Wacana, Yogyakarta.

Soetriono \& Rita Hanafie, 2007, Filsafat Ilmu dan Metodologi penelitian. Andi, Yogyakarta.

Wora, Emanuel, 2006, Perenialisme: Kritik atas Modernisme dan Postmodernisme, Kanisius, Yogyakarta.

Zaprulkhan, 2016, Filsafat Ilmu: Sebuah Analisis Kontenporer, PT Rajagrafindo Persada, Jakarta. 